\title{
PENGARUH JENIS PELARUT PADA EKSTRAKSI MENGGUNAKAN GELOMBANG ULTRASONIK TERHADAP AKTIVITAS ANTIOKSIDAN EKSTRAK KULIT BUAH LEMON (Citrus limon (Linn.) Burm F.)
}

\author{
Melia Verdiana ${ }^{1)}$, I Wayan Rai Widarta ${ }^{2)}$, I Dewa Gede Mayun Permana ${ }^{2)}$ \\ ${ }^{1)}$ Mahasiswa Program Studi Ilmu dan Teknologi Pangan, Fakultas Teknologi Pertanian, Unud \\ ${ }^{2}$ Dosen Program Studi Ilmu dan Teknologi Pangan, Fakultas Teknologi Pertanian, Unud \\ Kampus Bukit Jimbaran, Badung-Bali
}

\begin{abstract}
This study aims to determine the effect of solvent types on antioxidant activity of lemon peel (Citrus limon (Linn.) Burm F.) extract and to obtain the right solvent types with the highest antioxidant activity of lemon peel extract. The experimental design used in this research was a completely randomized design with the treatment of solvent types (aquades, acetone 70\%, ethanol 70\% and methanol 70\%). The treatment was repeated four times to obtain 16 units of the experiment. Data were analyzed with analysis of variance (ANOVA) and followed by Duncan test. The result showed that the best treatment was obtained extract with ethanol 70\% solvent with antioxidant activity was $52.72 \%$ and the IC50 value $471.33 \mathrm{mg} / \mathrm{L}$, followed by yield was 37.68\%, vitamin C was $227.90 \mathrm{mg} A A E / g$ extract and total flavonoid was $7.14 \mathrm{mg}$ QE/g extract.
\end{abstract}

Keywords : lemon peel, solvent types, ultrasonic, antioxidant activity, flavonoid.

\section{PENDAHULUAN}

Antioksidan diperlukan untuk mencegah terjadinya stres oksidatif, yang berperan penting dalam terjadinya berbagai penyakit degeneratif seperti kanker, penyakit jantung koroner dan stroke (Giacco dan Brownlee, 2010). Berbagai bukti ilmiah menunjukkan bahwa resiko penyakit kronis akibat senyawa radikal bebas dapat dikurangi dengan memanfaatkan peran senyawa antioksidan seperti vitamin $\mathrm{C}$, E, A, karoten, polifenol dan flavonoid (Okawa et al., 2001). Penggunaan bahan alami sebagai antioksidan diperlukan untuk meningkatkan kualitas kesehatan masyarakat. Bahan yang dapat digunakan yaitu limbah hasil olahan pangan seperti kulit buah lemon.

Menurut Ewanisha et al. (2006) kulit buah lemon mengandung berbagai macam senyawa yang mempunyai manfaat bagi kesehatan tubuh. Sembilan jenis senyawa fitokimia (saponin, alkaloid, flavonoid, anthraquinon, resin, tannin, terpen, steroid dan fenol) diketahui terdapat pada ekstrak kulit buah lemon. Selain itu, El-ghfar et al. (2016) melaporkan bahwa kulit buah lemon mengandung vitamin $\mathrm{C}$ dan flavonoid yang tinggi yaitu masing-ma Menurut Ewanisha et al. (2006) kulit buah lemon mengandung berbagai macam senyawa yang mempunyai manfaat bagi kesehatan tubuh. Sembilan jenis senyawa fitokimia (saponin, alkaloid, flavonoid, anthraquinon, resin, tannin, terpen, steroid dan fenol) diketahui terdapat pada ekstrak kulit buah lemon. Selain itu, El-ghfar et al. (2016) melaporkan bahwa kulit buah lemon mengandung vitamin $\mathrm{C}$

*Korespondensi Penulis:

Email: verdiana.melia@yahoo.com ${ }^{1}$ 
dan flavonoid yang tinggi yaitu masingmasing sebesar 77,64 mg/100g dan 390,75 mg QE/100 g sampel. Pengambilan senyawa flavonoid dan vitamin $\mathrm{C}$ pada kulit buah lemon dapat dilakukan melalui proses ekstraksi.sing sebesar 77,64 mg/100g dan 390,75 mg QE/100 g sampel. Pengambilan senyawa flavonoid dan vitamin $\mathrm{C}$ pada kulit buah lemon dapat dilakukan melalui proses ekstraksi.

Ekstraksi dapat dilakukan dengan beberapa metode yaitu maserasi, perkolasi dan sokletasi. Metode maserasi dapat dilakukan dengan beberapa cara, salah satunya maserasi yang dibantu dengan gelombang ultrasonik. Beberapa keunggulan penggunaan metode maserasi yang dibantu gelombang ultrasonik yaitu prosesnya tidak memerlukan biaya tinggi dan tidak memerlukan waktu yang lama, sehingga energi yang dikeluarkan tidak terlalu besar (Williams, 1983). Hal ini dikarenakan proses ekstraksi dengan bantuan gelombang ultrasonik dapat merusak permeabilitas dinding sel, menimbulkan gelembung spontan (kavitasi) dalam fase cair dibawah titik didihnya dan meningkatkan kerusakan pada sel (List dan Schmidt, 1989). Faktorfaktor yang mempengaruhi laju ekstraksi adalah tipe persiapan sampel, waktu ekstraksi, jumlah sampel, suhu, dan jenis pelarut (Utami, 2009).

Senyawa flavonoid bersifat polar sehingga dibutuhkan pelarut yang bersifat polar (Gillespie dan Paul, 2001). Efektivitas ekstraksi suatu senyawa oleh pelarut sangat tergantung kepada kelarutan senyawa tersebut dalam pelarut, sesuai dengan prinsip like dissolve like yaitu suatu senyawa akan terlarut pada pelarut dengan sifat yang sama. Pelarut yang bersifat polar diantaranya adalah etanol, metanol, aseton dan air (Sudarmadji et al., 1997).

Menurut Sayuti (2017) pelarut metanol menghasilkan aktivitas antioksidan tertinggi pada ekstrak bambu laut (Issis Hippuris).
Selain itu, aktivitas antioksidan tertinggi pada ekstrak kulit buah lemon diperoleh menggunakan pelarut etanol $70 \%$ dibandingkan metanol 80\% (El-ghfar et al., 2016). Menurut Champa et al. (2016) ekstraksi flavonoid pada Spirogyra sp. menggunakan pelarut aseton memberikan total flavonoid tertinggi. Namun, belum ditemukan jenis pelarut yang tepat untuk mendapatkan aktivitas antioksidan tertinggi dari kulit buah lemon. Oleh karena itu, perlu dilakukan penelitian agar diperoleh jenis pelarut yang tepat untuk mendapatkan aktivitas antioksidan tertinggi ekstrak kulit buah lemon.

\section{METODE PENELITIAN}

\section{Tempat dan Waktu}

Penelitian ini dilaksanakan di Laboratorium Pengolahan Pangan, Laboratorium Analisis Pangan Program Studi Ilmu dan Teknologi Pangan Fakultas Teknologi Pertanian, Universitas Udayana, Denpasar dan Laboratorium Biosains Universitas Udayana, Bukit Jimbaran. Waktu pelaksanaan penelitian dilakukan pada bulan Mei 2018 sampai dengan Juni 2018

\section{Bahan dan Alat}

Bahan-bahan yang digunakan dalam penelitian ini adalah kulit buah lemon lokal yang diperoleh dari UD Fenny Denpasar, aquades, aseton, etanol, metanol, $\mathrm{AlCl}_{3}$, $\mathrm{NaNO}_{2}, \mathrm{NaOH} 1 \mathrm{M}$ dan $\mathrm{DPPH}$ (Merck), asam sulfat $0,6 \mathrm{M}$, sodium fosfat dan ammonium molibdat.

Alat-alat yang digunakan yaitu pisau, oven (Blue M), blender (Miyako), ayakan60 mesh, timbangan analitik (Shimadzu), spatula, alumunium foil, gelas ukur, ultrasonic bath (Branson 2200), kertas Whatman no. 1, erlenmeyer, rotary vacuum evaporator (Ika Labortechnik), botol gelap, gelas beaker, spektrofotometer (Genesys $10 \mathrm{~s}$ $U v$-Vis), pipet volume, vortex, tabung reaksi, 
pipet miko dan water bath (Memmert).

\section{Rancangan Penelitian}

Penelitian ini menggunakan Rancangan Acak Lengkap (RAL) dengan perlakuan jenis pelarut yang terdiri atas 4 taraf yaitu: $\mathrm{P} 1=$ aquades, $\mathrm{P} 2=$ aseton $70 \%, \mathrm{P} 3=$ etanol $70 \%$ dan $\mathrm{P} 4=$ metanol $70 \%$. Perlakuan ini diulang sebanyak empat kali sehingga diperoleh 16 unit percobaan. Data dianalisis menggunakan metode analisis ragam (ANOVA) yang dilanjutkan dengan uji Duncan (Steel dan Torrie, 1993).

\section{Pelaksanaan Penelitian Pembuatan Bubuk Kulit Buah Lemon}

Kulit buah lemon dibersihkan dengan air untuk menghilangkan kotoran dan ditiriskan. Selanjutnya kulit buah lemon dipotong kecil-kecil dengan ukuran sekitar $3 \mathrm{~cm}$ x 3 $\mathrm{cm}$ dengan tujuan untuk mempermudah pengeringan dan penghancuran lalu dioven dengan suhu $55^{\circ} \mathrm{C}$ selama 15 jam. Setelah itu dihaluskan menggunakan blender, kemudian diayak menggunakan ayakan 60 mesh sehingga diperoleh bubuk kulit buah lemon (Bainiwal et al., 2013).

\section{Ekstraksi Kulit Buah Lemon}

Ekstraksi kulit buah lemon diawali dengan penimbangan bubuk kulit buah lemon masing-masing sebanyak $15 \mathrm{~g}$ lalu dilarutkan dengan variasi jenis pelarut (aquades, aseton $70 \%$, etanol $70 \%$ dan metanol $70 \%$ ) sebanyak $150 \mathrm{ml}$. Kemudian diekstraksi selama 60 menit menggunakan ultrasonic bath pada frekuensi $47 \mathrm{kHz}$. Selanjutnya larutan disaring menggunakan kertas Whatman No. 1. Filtrat yang diperoleh dievaporasi menggunakan rotary vacuum evaporator dengan suhu $40^{\circ} \mathrm{C}, 200 \mathrm{mBar}$ kecepatan 60rpm. Ekstrak yang didapat dikemas dengan botol gelap kemudian dianalisis rendemen, total flavonoid, aktivitas antioksidan dan vitamin C (El-ghfar et al., 2016 yang dimodifikasi).

\section{Parameter yang Diamati}

Parameter yang diamati pada penelitian ini meliputi rendemen ekstrak (AOAC,1990), vitamin C (Vuong et al., 2014), total flavonoid (Josipovic et al., 2016) dan aktivitas antioksidan dengan metode DPPH (Shah dan Modi, 2015).

\section{HASIL DAN PEMBAHASAN}

\section{Rendemen Ekstrak}

Hasil sidik ragam menunjukkan bahwa perlakuan jenis pelarut berpengaruh sangat nyata $(\mathrm{P}<0,01)$ terhadap rendemen ekstrak kulit lemon. Hubungan antara jenis pelarut terhadap rendemen ekstrak kulit buah lemon dapat dilihat pada Gambar 1.

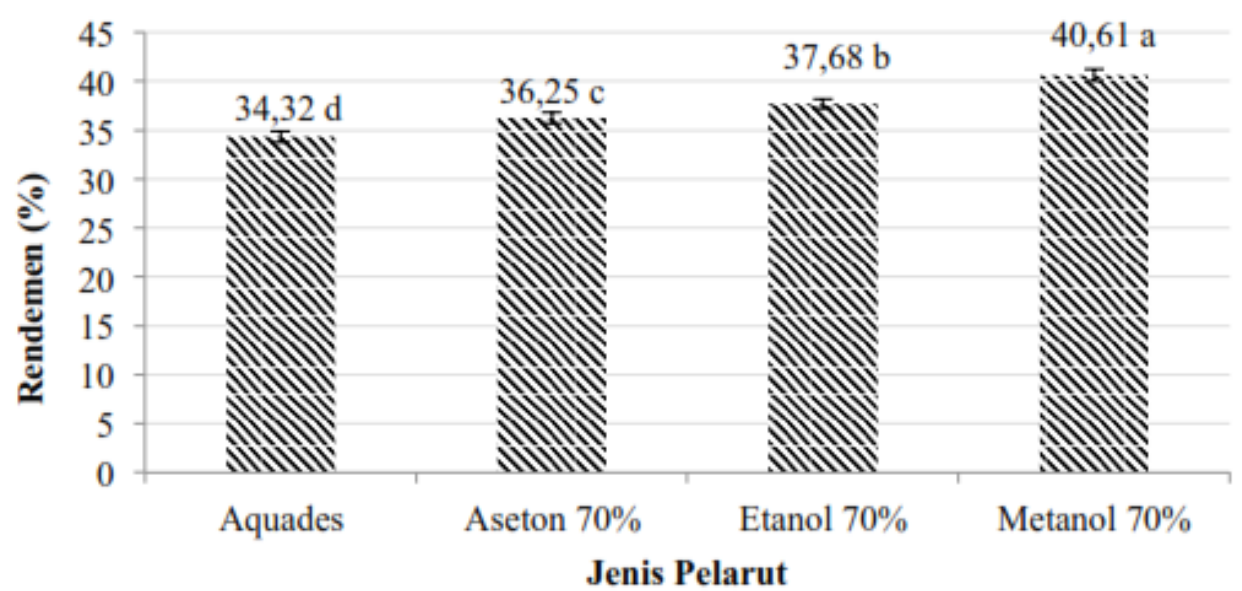

Gambar 1. Hubungan antara jenis pelarut terhadap rendemen ekstrak kulit buah lemon 
Keterangan: Notasi yang sama menunjukkan pengaruh perlakuan tidak berbeda nyata $(\mathrm{P}>0,05)$

Gambar 1 menunjukkan bahwa rendemen ekstrak kulit buah lemon tertinggi diperoleh menggunakan pelarut metanol $70 \%$ yaitu $40,61 \%$ sedangkan rendemen terendah terdapat pada pelarut aquades yaitu $34,32 \%$. Penggunaan jenis pelarut dengan perbedaan polaritas dapat memberikan pengaruh terhadap rendemen yang dihasilkan. Pelarut organik berdasarkan konstanta dielektriknya dapat dibedakan menjadi dua yaitu pelarut polar dan non polar. Konstanta dielektrik dinyatakan sebagai gaya tolak menolak antara dua pertikel yang bermuatan listrik dalam suatu molekul. Semakin tinggi konstanta dielektriknya maka pelarut bersifat semakin polar. Konstanta dielektrik pada air, metanol, etanol dan aseton masing-masing mempunyai nilai yaitu 80, 33, 24 dan 21 (Sudarmadji et al., 1997).

Tingginya rendemen ekstrak kulit buah lemon dengan pelarut metanol menunjukkan bahwa pelarut metanol pada kulit buah lemon mampu mengekstrak senyawa lebih baik, karena perolehan senyawa didasari oleh kesamaan sifat kepolaran terhadap pelarut. Menurut Ewanisha et al. (2006) kulit lemon mengandung metabolit sekunder seperti alkaloid, steroid, saponin, tannin, flavonoid dan fenol. Selain itu, senyawa seperti karbohidrat, asam lemak, protein, vitamin $\mathrm{A}$, vitamin $\mathrm{C}$ dan vitamin $\mathrm{E}$ juga terdapat pada kulit lemon (Nizhar, 2012). Metanol dapat menarik senyawa flavonoid, saponin, tanin dan terpenoid pada tanaman (Astarina et al., 2013). Selain itu, metanol merupakan pelarut yang bersifat universal sehingga dapat menarik sebagian besar senyawa yang bersifat polar dan non polar pada bahan (Salamah dan Widyasari, 2015).

Hal ini sesuai dengan penelitian yang dilakukan Mardawati et al. (2008) bahwa ekstraksi dengan pelarut metanol menghasilkan rendemen ekstrak kulit manggis yang lebih tinggi dibandingkan dengan pelarut etanol dengan konsentrasi yang sama. Demikian juga pada ekstrak biji barley, rendemen tertinggi diperoleh menggunakan pelarut metanol dibandingkan etanol dan aseton (Liu dan Yao, 2007).

\section{Vitamin C}

Hasil sidik ragam menunjukkan bahwa perlakuan jenis pelarut berpengaruh sangat nyata $(\mathrm{P}<0,01)$ terhadap kandungan vitamin $\mathrm{C}$ ekstrak kulit buah lemon. Hubungan antara jenis pelarut terhadap vitamin $\mathrm{C}$ ekstrak kulit buah lemon dapat dilihat pada Gambar 2.

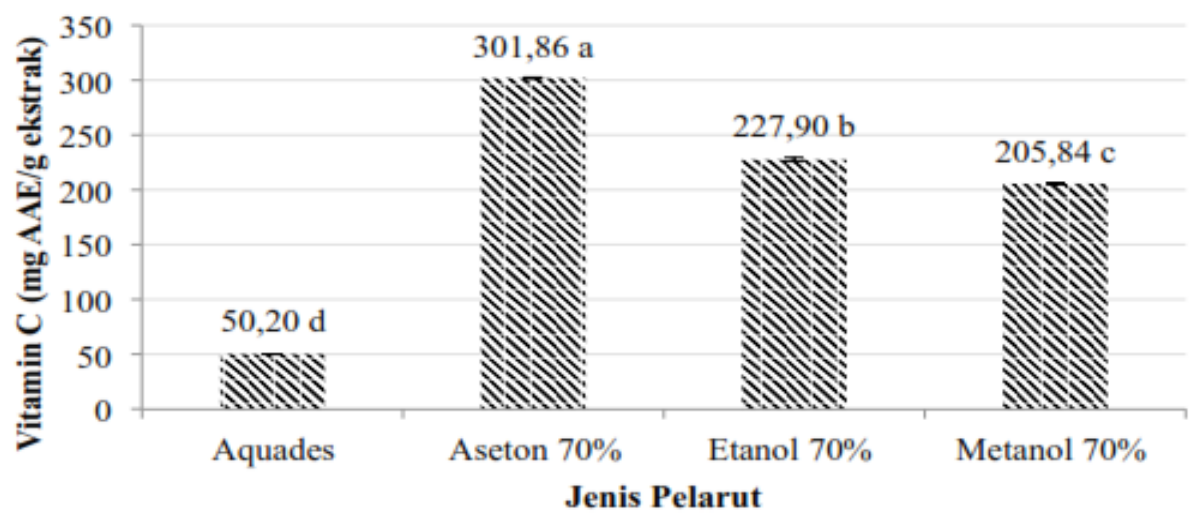

Gambar 2. Hubungan antara jenis pelarut terhadap vitamin C ekstrak kulit buah lemon 
Keterangan: Notasi yang sama menunjukkan pengaruh perlakuan tidak berbeda nyata $(\mathrm{P}>0,05)$

Gambar 2 menunjukkan bahwa vitamin C tertinggi diperoleh menggunakan pelarut aseton $70 \%$ yaitu $301,86 \mathrm{mg}$ AAE/g ekstrak, sedangkan kandungan vitamin $\mathrm{C}$ terendah diperoleh menggunakan pelarut aquades yaitu 50,20 mg AAE/g ekstrak. Hasil ini mengindikasikan bahwa pelarut yang kepolarannya lebih rendah mampu mengekstrak vitamin $\mathrm{C}$ dengan lebih efektif. Aseton merupakan pelarut semi-polar yang dapat menarik senyawa polar dan semi-polar (Troy, 2005). Menurut Zumdahl (2007) vitamin $\mathrm{C}$ memiliki banyak ikatan polar $\mathrm{O}$ $\mathrm{H}$ dan $\mathrm{C}-\mathrm{O}$ sehingga membuat vitamin $\mathrm{C}$ bersifat polar dan dapat terekstrak baik oleh pelarut aseton.

Hal ini didukung dengan penelitian Dumbrava et al. (2012) bahwa pelarut aseton menghasilkan vitamin $\mathrm{C}$ yang lebih tinggi dibandingkan dengan etanol dan air pada ekstrak buah jeruk dan plum. Pelarut aseton juga menghasilkan vitamin $\mathrm{C}$ tertinggi pada ekstrak tomat (Eveline et al., 2014). Selain itu, menurut Wenzig et al. (2008) kadar vitamin $\mathrm{C}$ pada ekstrak metanol kelopak bunga mawar lebih tinggi daripada ekstrak airnya. Demikian juga pada ekstrak salak pondoh, nglumut dan bali menggunakan pelarut etanol lebih tinggi daripada menggunakan pelarut aquades (Ariviani dan Parnanto, 2013).

\section{Total Flavonoid}

Hasil sidik ragam menunjukkan bahwa perlakuan jenis pelarut berpengaruh sangat nyata $(\mathrm{P}<0,01)$ terhadap total flavonoid ekstrak kulit buah lemon. Hubungan antara jenis pelarut terhadap total flavonoid ekstrak kulit buah lemon dapat dilihat pada Gambar 3. Berdasarkan Gambar 3 total flavonoid tertinggi diperoleh menggunakan pelarut etanol $70 \%$ yaitu $7,14 \mathrm{mg}$ QE/g ekstrak dan total flavonoid terendah diperoleh menggunakan pelarut aquades yaitu 4,34 $\mathrm{mg}$ QE/g ekstrak.

Suatu senyawa akan larut pada pelarut yang mempunyai kepolaran yang sama. Senyawa flavonoid terbagi menjadi beberapa jenis, tiap jenis flavonoid mempunyai kepolaran yang berbeda-beda tergantung dari jumlah dan posisi gugus hidroksil tiap jenis flavonoid sehingga hal tersebut akan mempengaruhi kelarutan flavonoid pada pelarut (Harborne, 1996). Total flavonoid pada ekstrak kulit buah lemon dengan pelarut etanol menunjukkan bahwa pelarut etanol memiliki tingkat kepolaran yang menyerupai dan lebih efektif dalam melarutkan senyawa flavonoid pada kulit buah lemon, sehingga ekstrak kulit buah lemon menggunakan pelarut etanol menghasilkan senyawa flavonoid tertinggi.

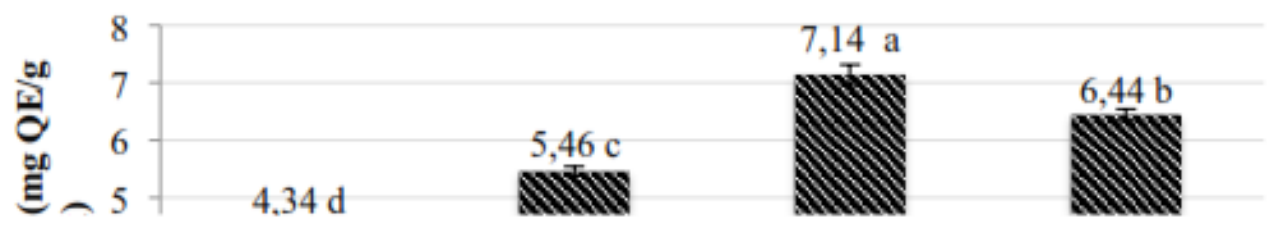

Gambar 3. Hubungan antara jenis pelarut terhadap total flavonoid ekstrak kulit buah lemon

Keterangan: Notasi yang sama menunjukkan pengaruh perlakuan tidak berbeda nyata $(\mathrm{P}>0,05)$

Menurut Alothman et al. (2009) kadar total flavonoid buah nanas lebih tinggi 
diperoleh menggunakan pelarut etanol dibandingkan air, metanol dan aseton pada konsentrasi pelarut yang sama. Ekstrak kulit buah lemon menggunakan pelarut aquades menghasilkan total flavonoid terendah dimana pelarut aquades merupakan pelarut yang paling polar dibandingkan pelarut lainnya, sehingga komponen yang bersifat polar seperti karbohidrat ikut terekstrak dan menyebabkan total flavonoid per berat sampel menjadi rendah (Septiana dan Asnani, 2012).

\section{Aktivitas Antioksidan}

Hasil sidik ragam menunjukkan bahwa perlakuan jenis pelarut berpengaruh sangat nyata $(\mathrm{P}<0,01)$ terhadap aktivitas antioksidan ekstrak kulit buah lemon. Hubungan antara jenis pelarut terhadap aktivitas antioksidan ekstrak kulit buah lemon dapat dilihat pada Gambar 4. Gambar 4 menunjukkan bahwa aktivitas antioksidan tertinggi diperoleh pada pelarut etanol $70 \%$ yaitu $52,72 \%$, sedangkan aktivitas antioksidan terendah diperoleh pada pelarut aquades yaitu 25,35\%. Menurut El-ghfar et al. (2016) ekstrak kulit buah lemon menggunakan pelarut etanol memiliki aktivitas antioksidan tertinggi yaitu 52,64\%. Aktivitas antioksidan dapat dipengaruhi oleh jumlah senyawa flavonoid yang ada pada ekstrak kulit buah lemon, semakin banyak senyawa flavonoid maka aktivitas antioksidan akan semakin meningkat.

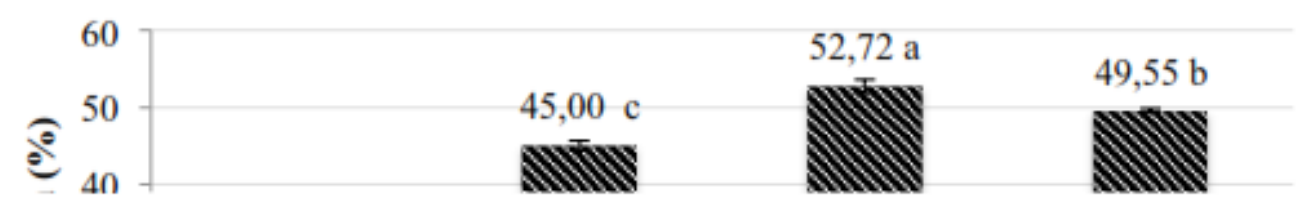

Gambar 4. Hubungan antara jenis pelarut terhadap aktivitas antioksidan ekstrak kulit buah lemon

Keterangan: Notasi yang sama menunjukkan pengaruh perlakuan tidak berbeda nyata $(\mathrm{P}>0,05)$

Hal ini sesuai dengan data yang diperoleh bahwa semakin tinggi total flavonoid pada berbagai jenis pelarut, maka semakin tinggi pula aktivitas antioksidan. Grafik hubungan antara total flavonoid dengan aktivitas antioksidan ekstrak kulit buah lemon dapat dilihat pada Gambar 5. Gambar 5 menunjukkan korelasi total flavonoid dengan aktivitas antioksidan dengan perlakuan jenis pelarut.

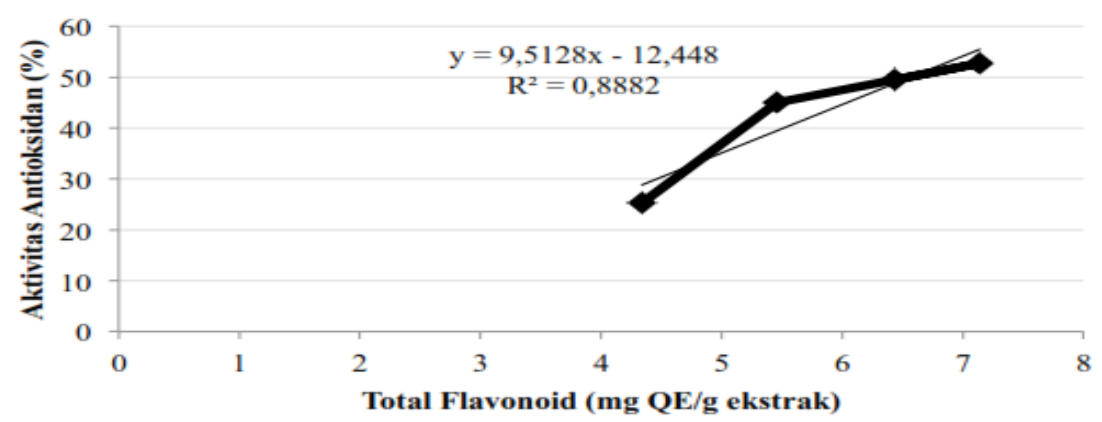

Gambar 5. Grafik hubungan antara total flavonoid dengan aktivitas antioksidan ekstrak kulit buah lemon 
Menurut Sarwono (2006) koefisien korelasi $\left(\mathrm{R}^{2}\right)$ yang mempunyai nilai $>0,75$ 0,99 dapat dikategorikan sebagai berkorelasi sangat kuat. Berdasarkan data yang diperoleh, koefisien korelasi $\left(\mathrm{R}^{2}\right)$ antara total flavonoid dan aktivitas antioksidan ekstrakkulit buah lemon yaitu 0,89 sehingga dapat disimpulkan bahwa aktivitas antioksidan ekstrak kulit lemon dipengaruhi oleh total flavonoid. Hal ini serupa dengan yang dilaporkan Alothman et al. (2009) bahwa terdapat korelasi positif antara total flavonoid dengan aktivitas antioksidan pada ekstrak buah nanas, pisang mas dan jambu.

Berdasarkan hasil analisis aktivitas antioksidan, pelarut etanol $70 \%$ memiliki persentase aktivitas antioksidan tertinggi sehingga perlakuan ini dipilih untuk diuji penentuan $\mathrm{IC}_{50}$. Grafik hubungan antara konsentrasi ekstrak dengan aktivitas antioksidan ekstrak kulit buah lemon menggunakan pelarut etanol $70 \%$ dapat dilihat pada Gambar 6.

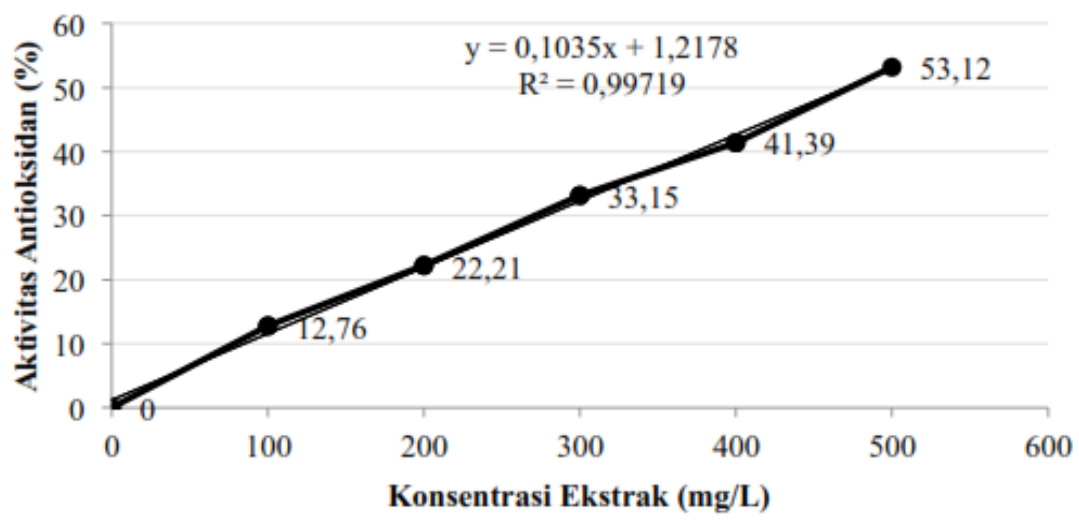

Gambar 6. Grafik hubungan antara konsentrasi ekstrak dengan aktivitas antioksidan ekstrak kulit buah lemon menggunakan pelarut etanol $70 \%$

Gambar 6 menunjukkan bahwa semakin tinggi konsentrasi ekstrak maka semakin tinggi persentase aktivitas antioksidan. Berdasarkan analisis regresi linier diperoleh persamaan yaitu $\mathrm{y}=0,1035 \mathrm{x}+1,2178$ dengan nilai $\mathrm{IC}_{50}$ sebesar $471,33 \mathrm{mg} / \mathrm{L}$. $\mathrm{IC}_{50}$ menggambarkan besarnya konsentrasi suatu seyawa yang mampu menghambat radikal bebas (DPPH) sebanyak $50 \%$. Jika nilai $\mathrm{IC}_{50}$ semakin kecil maka kemampuan antioksidan semakin besar (Senevirathne et al., 2006).

\section{SIMPULAN DAN SARAN}

\section{Simpulan}

Berdasarkan hasil penelitian yang telah dilakukan, maka dapat disimpulkan beberapa hal sebagai berikut :
1. Jenis pelarut berpengaruh sangat nyata terhadap rendemen, vitamin $\mathrm{C}$, total flavonoid dan aktivitas antioksidan ekstrak kulit buah lemon.

2. Hasil penelitian terbaik menunjukkan bahwa pelarut etanol $70 \%$ menghasilkan aktivitas antioksidan tertinggi yaitu $52,72 \%$ dan nilai IC50 sebesar 471,33 $\mathrm{mg} / \mathrm{L}$, diikuti dengan rendemen 37,68 \%, vitamin C 227,90 mg AAE/g ekstrak dan total flavonoid 7,14 mg QE/g ekstrak.

\section{Saran}

Perlu dilakukan penelitian lebih lanjut tentang teknologi mikroenkapsulasi ekstrak kulit buah lemon sehingga dapat dimanfaatkan sebagai sumber antioksidan pada bahan pangan. 


\section{DAFTAR PUSTAKA}

Alothman, M., A.A. Karim, dan R. Bhat. 2009. Antioxidant capacity and phenolic content of selected tropical fruits from Malaysia extracted with different solvents. Food Chemistry. 115: 785-788.

AOAC. 1990. Official Method of Analysis of Association Official Agriculture Chemist. Washington DC.

Ariviani, S dan N.H.R Parnanto. 2013. Kapasitas antioksidan buah salak (Salacca edulis REINW) kultivar Pondoh, Nglumut dan Bali serta korelasinya dengan kadar fenolik total dan vitamin c. Agritech. 33(3): 324333.

Astarina, N.G.H., K.W. Astuti dan N.K. Warditiani. 2013. Skrining fitokimia ekstrak metanol rimpang bangle (Zingiber purpureum Roxb.). Jurnal Farmasi Udayana. 2 (4).

Bainiwal, L. K., V. Pratima dan V. Tekha. 2013. Determination of preliminary phytoconstituents, total phenolic and flavonoids contents in the roots, leaves and stems of (Cleome viscosa Linn). International Journal of Biological and Pharmaceutical Research. 4(12): 891-895.

Champa, P., N. Whangchai, S. Jaturonglumlert, N. Nakao dan K. Whangchai. 2016. Determination of phytochemical compound from Spirogyra sp. using ultrasonic assisted extraction. International Journal of Geomate. 11(24): 23912396.

Dumbrava, D.G., C. Moldovan, D.N. Raba dan M.V. Popa. 2012. Comparative analysis of vitamin $\mathrm{C}$ content and antioxidant activity of some fruits extracts. Journal of Agroalimentary Processes and Technologies. 18(3): 223-228.

El-ghfar, M.H.A.A., H.M. Ibrahim, I.M. Hassan, A.A.A. Fattah dan M.H. Mahmoud. 2016. Peels of lemon and orange as value-added ingredients: chemical and antioxidant properties. International Journal of Current Microbiology and Applied Sciences. 5(12): 777-794.

Eveline, T.M. Siregar dan Sanny. 2014. Studi aktivitas antioksidan pada tomat (Lycopersicon esculentum) konvensional dan organik selama penyimpanan. Prosiding Seminat Nasional Sains dan Teknologi. 5: 2228.

Ewanisha, J.U., S.A. Garba, M. Galadima, S.Y. Daniyan dan M.B. Busari. 2006. Therapeutic potency of Citrus limon (1) burm. F. (lemon) peel extract against some disease causing microorganisms. International Journal of Research Studies in Biosciences. 4(11) : 30-39.

Giacco, F. dan M. Brownlee. 2010. Oxidative stress and diabetic complications. Journal of The American Heart Association. 107: 1058-1070.

Gillespie, R.J. dan Paul. 2001. Chemical Bonding and Molecular Geometry. Oxford University Press, London.

Harborne, J.B. 1996. Metode Fitokimia: Penuntun Cara Modern Menganalisis Tumbuhan. ITB Press, Bandung.

Josipovic, A., R. Sudar, A. Sudaric, V. 
Jurkovic, M.M. Kocar dan A.M. Kulundzic. 2016. Total phenolic and total flavonoid content variability of soybean genotypes in eastern croatia. Croatia Journal Food Science Technology. 8(2): 60-65.

List, P.H dan P.C. Schmidt. 1989. Phytopharmaceutical Technology. CRC Press, Boston. Liu, Q dan H. Yao. 2007. Antioxidant activities of barley seeds extract. Food Chemistry. 107: 732-737.

Mardawati, E., C.S. Achyar dan H. Marta. 2008. Kajian Aktivitas Antioksidan Ekstrak Kulit Manggis (Garcinia mangostana L) Dalam Rangka Pemanfaatan Limbah Kulit Manggis di Kecamatan Puspahiang Kabupaten Tasikmalaya. Laporan Akhir Penelitian Peneliti Muda. Tidak dipublikasikan. Fakultas Teknologi Industri Pertanian Universitas Padjadjaran, Bandung.

Nizhar, U. 2012. Level Optimum Sari Buah Lemon (Citrus limon) Sebagai Bahan Penggumpal Pembuatan Keju Cottage. Skripsi. Tidak dipublikasikan. Fakultas Peternakan Universitas Hassanuddin, Makassar.

Okawa M., J. Kinjo, T. Nohara dan M. Ono. 2001. DPPH (1,1-diphenyl-2picrylhydrazyl) radical scavenging activity of flavonoids obtained from some medicinal plants. Biology Pharmacy Journal. 24(10): 12021205.

Salamah, N. dan E. Widyasari. 2015. Aktivitas antioksidan ekstrak metanol daun kelengkeng (Euphoria longan (L) Steud.) dengan metode penangkapan radikal 2,2'-difenil-1pikrilhidrazil. Pharmaciana. 5(1): 25-
34.

Sarwono, J. 2006. Metode Penelitian Kuantitatif dan Kualitatif. Graha Ilmu, Yogyakarta. Sayuti, M. 2017. Pengaruh perbedaan metode ekstraksi, bagian dan jenis pelarut terhadap rendemen dan aktivitas antioksidan bambu laut (Isis hippuris). Technology Science and Engineering Journal. 1(3):166-174.

Senevirathne, M., S. Kim, N. Siriwardhana, J. Ha, K. Lee dan Y. Jeon. 2006. Antioxidant potential of Ecklonia cava on reactive oxygen species scavenging, metal chelating, reducing power and lipid peroxidation inhibition. Food Science and Technology International. 12: 27-38.

Septiana, A.T dan A. Asnani. 2012. Kajian sifat fisikokimia ekstrak rumput laut Sargassum duplicatum menggunakan berbagai pelarut dan metode ekstraksi. Agrointek. 6(1): 22-28.

Shah, P dan H.A. Modi. 2015. Comparative study of DPPH, ABTS and FRAP assays for determination of antioxidant activity. International Journal for Research in Applied Science and Engineering Technology. 3(6): 636641.

Steel, R.G.D dan J.H. Torrie. 1993. Prinsip dan Prosedur Statistika Suatu Pendekatan Biometrik. Penerjemah B. Sumantri. PT. Gramedia Pustaka, Jakarta. Sudarmadji, S., B. Haryon dan Suhardi. 1997. Prosedur Analisis untuk Bahan Makanan dan Pertanian. Penerbit Liberti, Yogyakarta.

Troy, D.B. 2005. The Science and Practice of Pharmacy. Lippincott Williams and Wilikins, Philadelphia. 
Utami. 2009. Potensi daun alpukat (Persea americana Mill) sebagai sumber antioksidan alami. Jurnal Teknik Kimia UPN Jawa Timur. 2(1) : 58-64.

Vuong, Q. V., S. Hirun, T.L.K. Chuen, C.D. Goldsmith, M.C. Bowyer, A.C. Chalmers, P.A. Phillips dan C.J. Scarlett. 2014. Physicochemical composition, antioxidant and antiproliferative capacity of a lily pilly (Syzygium paniculatum) extract. Journal of Herbal Medicine. 10: 1016.

Wenzig, E.M., U. Widowitz, O. Kunert, S. Chrubasik, F. Bucar, E. Knauder dan R. Bauer. 2008. Phytochemical composition and in vitro pharmacological activity of two rose hip (Rosa canina L.) preparations. Journal Phytomedicine. 15: 826-835.

Williams, A.R. 1983. Panel Discussion on Mechanisms and Biological Effects. Academic Press.

Zumdhal, S.S. 2007. Chemical Principles. Cengage Learning, Boston 